\title{
RECENT TRENDS IN DENGUE DETECTION METHODS USING BIOSENSORS
}

\author{
AHMAd ANWAR ZAINUdDin*, ANIS NURASHIKIN NORDIN \\ AND ROSMINAZUIN AB RAHIM \\ Department of Electrical and Computer Engineering, \\ Kulliyyah of Engineering, International Islamic University Malaysia, \\ PO Box 10, 50728 Kuala Lumpur, Malaysia. \\ "Corresponding author: mr.anwarzain@gmail.com \\ (Received:30 ${ }^{\text {th }}$ April 2018; Accepted: $11^{\text {th }}$ July 2018; Published on-line: $1^{\text {st }}$ Dec 2018) \\ https://doi.org/10.31436/iiumej.v19.i2.931
}

\begin{abstract}
Dengue illness is an infectious tropical disease, transmitted by Aedes mosquitos, that poses a serious health threat to the tropical world. This disease causes widespread infection worldwide, with about 50 million cases of dengue occurring per annum out of which 500,000 recorded cases of dengue hemorrhagic fever and 22,000 deaths. Currently, there are no effective vaccines available to prevent the spread of the infection. Accurate and rapid laboratory diagnostic tests are required for early detection to reduce patient mortality rate. In this paper, common laboratory diagnosis methods for detecting dengue virus infection are discussed. Currently, virus isolation, RT-PCR and serology methods provide the most direct and accurate response for detection of dengue. However, these methods require tedious steps, expensive requirements and expert staffs. Recent research have proposed the usage of biosensors as an alternative new technology for detection of dengue. In this work, various types of biosensors such as electrochemical, piezoelectric, and optical biosensor have been described and compared to evaluate their effectiveness in dengue detection. It is observed that the optical biosensor offers the best detection due to its high sensitivity as compared to others, although it is popularly known as an expensive method. Alternatively, the use of electrochemical and piezoelectric biosensors (QCM) is highly recommended for detection of dengue due to their ease-of-use, low cost, low reagent consumption, disposability, and minimal sample preparation. These approaches have the potential to improve the rate of survival, particularly in resource-limited countries.
\end{abstract}

ABSTRAK: Virus denggi adalah penyakit berjangkit tropika bawaan nyamuk Aedes yang menimbulkan ancaman serius kepada kesihatan global. Penyakit ini menyebabkan jangkitan yang meluas di seluruh dunia, dengan kira-kira 50 juta kes denggi yang berlaku setiap tahun di mana 500,000 kes demam denggi berdarah dan 22,000 kematian direkodkan. Buat masa ini, tiada vaksin yang berkesan untuk mencegah penyebaran jangkitan ini. Ujian diagnostik makmal yang cepat dan tepat diperlukan untuk pengesanan denggi awal untuk mengurangkan kadar kematian pesakit. Dalam artikel ini, kaedah diagnosis makmal yang biasa dilakukan untuk mengesahkan jangkitan virus denggi akan dibincangkan. Pada masa kini, kaedah pengasingan virus, RT-PCR dan serologi adalah tindak balas yang paling cepat dan tepat untuk mengesan denggi. Walau bagaimanapun, kaedah-kaedah ini memerlukan langkah-langkah yang melecehkan, kos penyelenggaraan yang tinggi dan kakitangan yang terlatih. Penyelidikan terkini telah mencadangkan penggunaan biosensor sebagai teknologi baru alternatif untuk mengesan denggi. Dalam artikel ini juga pelbagai jenis biosensor seperti 
biosensor elektrokimia, piezoelektrik, dan biosensor optik telah dijelaskan dan dibandingkan untuk menilai keberkesanannya dalam pengesanan denggi. Difahamkan bahawa biosensor optik menawarkan pengesanan terbaik kerana kepekaannya yang tinggi berbanding dengan yang lain, walaupun ia dikenali sebagai kaedah berkos tinggi. Sebaliknya, biosensor elektrokimia dan piezoelektrik (QCM) sangat disyorkan untuk mengesan denggi kerana ia mudah digunakan, berkos rendah, penggunaan bahan uji yang terhad, boleh dipakai buang, dan mempunyai penyediaan sampel yang minima. Pendekatan-pendekatan ini berpotensi untuk meningkatkan kadar kemandirian di kawasan-kawasan sumber terhad.

KEYWORDS: DENV E-protein; NS1; laboratory methods; biosensors

\section{INTRODUCTION}

Dengue is a rapid-spreading, febrile, mosquito-borne viral disease caused by the dengue virus, which is prevalent in most tropical and subtropical regions. In the past century, denguerelated incidents have increased by approximately thirty fold, where an estimated 50 million cases of dengue occur per annum with 500,000 recorded cases of dengue hemorrhagic fever and 22,000 deaths [1]. The disease has been endemic to Southeast Asia, where epidemic dengue is a major public health problem in Indonesia, Sri Lanka, Thailand, and Timor Leste [2]. The dengue epidemic causes significant health, social, and economic burdens particularly in affected areas [2]. While dengue outbreaks often occur in urban areas such as Jakarta and West Java where cases number in the hundreds of thousands, focal outbreaks in rural areas have higher fatality rates of $3-5 \%$ compared to $1 \%$ in urban areas. The average annual number of dengue fever and dengue hemorrhagic fever cases that have been reported to WHO is shown in Fig. 1(a). Due to the rapid-spread nature of the disease and its high fatalities, dengue is a threat for health security that can constitute a public health emergency of international concern as it can cause a borderless epidemic across several countries [1]. Decreasing the number of outbreaks and if possible eliminating the disease altogether are indeed of the utmost importance. As of recently, there are no specific vaccines to treat dengue except the CYD-TDV (Dengvaxia, Sanofi Pasteur), the first licensed dengue vaccine that is approved by the U.S. Food and Drug Administration (FDA). However this vaccine is compromised by several limitations such as being restricted to patients who have experienced previous DENV infection [3-4].

The dengue virus belongs to the Flavivirus genus of the Flaviviridae family. In terms of human infection, dengue fever could lead to a wide spectrum of illnesses, ranging from mild febrile illnesses to fatal hemorrhagic diseases. Figure 1(b) shows the course of dengue illness over a period of 10 days. The entire course of the illness can be categorized into three phases such as febrile, critical, and recovery. Dengue patients normally have dengue fever or viremia in the early stage. In this stage, the patient has dehydration and low levels of hematocrit. Signs and symptoms of dengue fever include high fever $\left(40{ }^{\circ} \mathrm{C}\right)$, headaches, nausea, vomiting, joint pain, fatigue, and rashes. During the critical phase, the patients get worse where the hematocrit level starts to increase and the platelet level starts to decrease. In this phase also, the temperature of the patients will drop and may progress to shock bleeding, which can result in death if not managed properly [5]. During the recovery phase, the platelet level returns back to normal or increases, the hematocrit level reduces and temperature gets back to normal. Some of infected patients may experience severe complications such as dengue hemorrhagic fever (DHF) and dengue shock syndrome (DSS), which have high risk of death. Additional symptoms in 
DHF/DSS cases include plasma leakage from blood vessels, fluid accumulation in the chest, blood concentration increase, organ dysfunction, and severe bleeding [1]. Furthermore, severe DHF/DSS commonly happen when the patients get a second dengue infection thereafter [1].

Several warning signs for severe dengue include persistent vomiting, mucosal bleeding, lethargy, abdominal pain or tenderness, clinical fluid accumulation, restlessness, liver enlargement of more than $2 \mathrm{~cm}$, and an increase in the hematocrit count with a rapid decrease in platelet count [1]. Patients usually recover if identified early and with proper fluid and electrolyte administration [6-8].
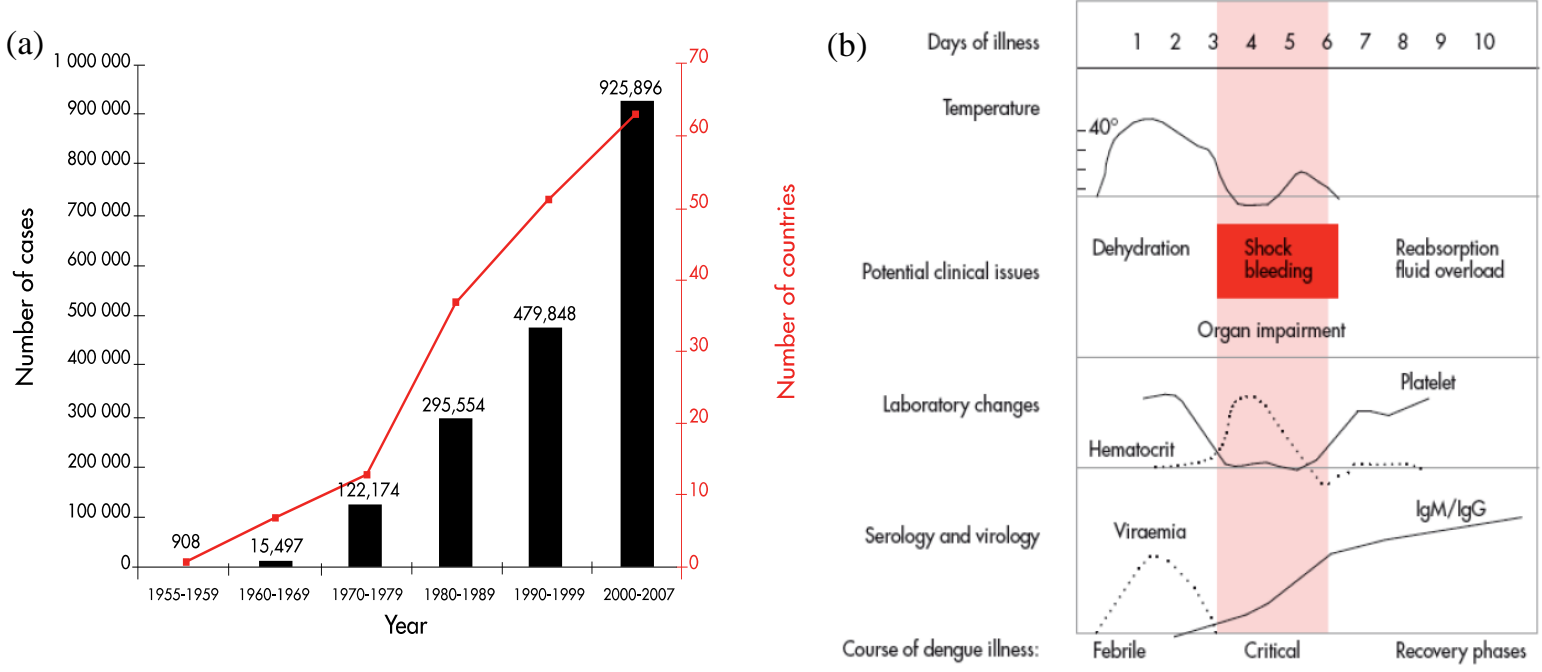

Fig. 1: (a) Average annual number of dengue fever and dengue haemorrhagic fever cases reported to WHO and number of countries reporting dengue from 1955-2007 [1].

(b) The course of dengue illness over a period of 10 days [1].

\section{DENGUE DETECTION METHODS}

\subsection{Overview}

The rapid nature of dengue illness, which can progress from mild to severe within a few days, makes it necessary to have a quick diagnostic test for proper treatment. The optimal window for diagnosing a dengue infection is typically from the onset of fever until 10 days post-infection [9]. Early diagnosis should be able to distinguish dengue from other diseases such as malaria, leptospirosis, typhoid, typhus, and Chikungunya, all of which present similar symptoms [10]. Recently, much of work in early detection of dengue via biosensor was reported to play an important role due to their cost effective method, rapid measurements and high efficiency in bio-sensing analyses as compared to common conventional methods [11-12].

Among parameters that can be used to evaluate biosensors are specificity, selectivity, limit of detection (LOD), and sensitivity. The selectivity and specificity are evaluated to study the reliability tests of the analytical response. These reliability tests also can help to improve the issue of cross reactivity or false-positive tests of specific detection in bio-sensing layers. Based on the International Union of Pure and Applied Chemistry (IUPAC) guidelines, all these parameters are defined accordingly in this paper [13-14]. 
Specificity is defined when the analyte alone is responsible for the relative signal that is measured with great accuracy. Selectivity refers to the quality of response of the method that can be achieved to discriminate a particular analyte without interference from any other component in a mixture via quantitative or qualitative method. In the quantitative method, a complex evaluation is acquired via computational selectivity based on a multivariate statistical method such as chemometric and classification methods. In this regard, the use of the qualitative method has been widely adopted in spectroelectrochemical sensors based on three levels of selectivity that can be determined from an ion-exchange protein on the electrode, potential selection, and wavelength. Furthermore, this method directly reflects the considerations among analytical chemists to optimize the selectivity [15].

Limit of detection (LOD) is the lowest concentration level that can be determined to be statistically different from an analytical blank [16]. Sensitivity $(m)$ is the magnitude of the response per unit concentration within the dynamic range of the instrument [16]. In general, LOD and sensitivity can be quantitatively calculated via a calibration plot derived from at least triplicate of data measurement $(\mathrm{k} \geq 3)$ in accordance with the confidence level of $99.86 \%$. In fact, these measurements are assumed to follow a normal distribution of the raw analytical signals from blank samples. These measurements, within the context of this study, are the signal responses towards varied concentrations of target analytes. Figure 2 shows the LOD, which represented as the concentration, $c_{L}$, is expressed as Eq.(1) [16]:

$$
c_{L}=\frac{k S_{B}}{m}
$$

where $k=3$ is the minimum numerical factor (number of experiments). $S_{B}$ is the standard deviation of number of blanks reading. $m$ is defined as the sensitivity in analytical chemistry, which is evaluated from slope of the calibration curve.

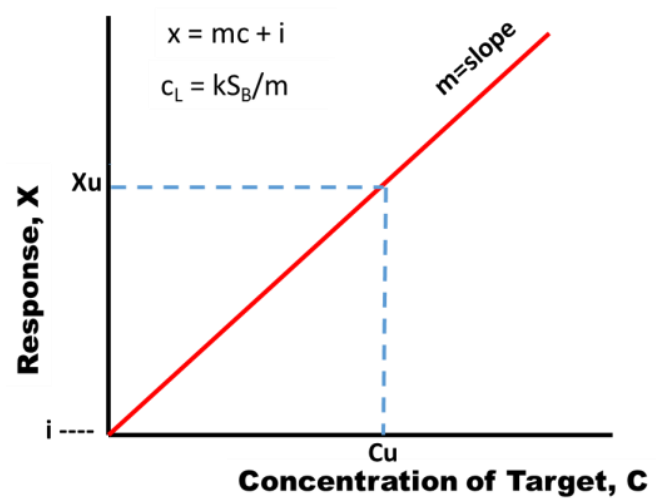

Fig. 2: Analytical calibration curve of response, $\mathrm{X}$ vs. concentration of target, $\mathrm{C}$, showing the relationship of $k S_{B}$ to the limit of detection, $c_{L}$. The unknown signal, $\mathrm{x}_{\mathrm{U}}$, is referred to an unknown concentration, $\mathrm{c}_{\mathrm{U}}$ via the equation $x=m c+i$, where $m$ is the slope and $i$ is the $\mathrm{y}$ intercept [16].

\subsection{Conventional Methods}

Figure 3 presents an overview of the common laboratory methods for diagnosing dengue. The methods can be categorized into detection of virus, genome, antigen, and serological methods [17]. Virus isolation, genome detection, and antigen detection provide higher 
specificity compared to serological methods. However, serology offers better practicality and widespread use due to its lower cost and easier sample handling, assay operations, and operator training. Direct virus detection of live virus or virus components (RNA or antigens) can be done in serum, plasma, whole blood, and infected tissues can be used for early identification of dengue infections during the acute phase (viremia) of the disease [18-19]. Direct virus detection procedures are not routinely performed by laboratories, and few commercial kits that have been independently validated are available to aid in this area of dengue diagnosis. The details of each detection are explained further in the following sections.

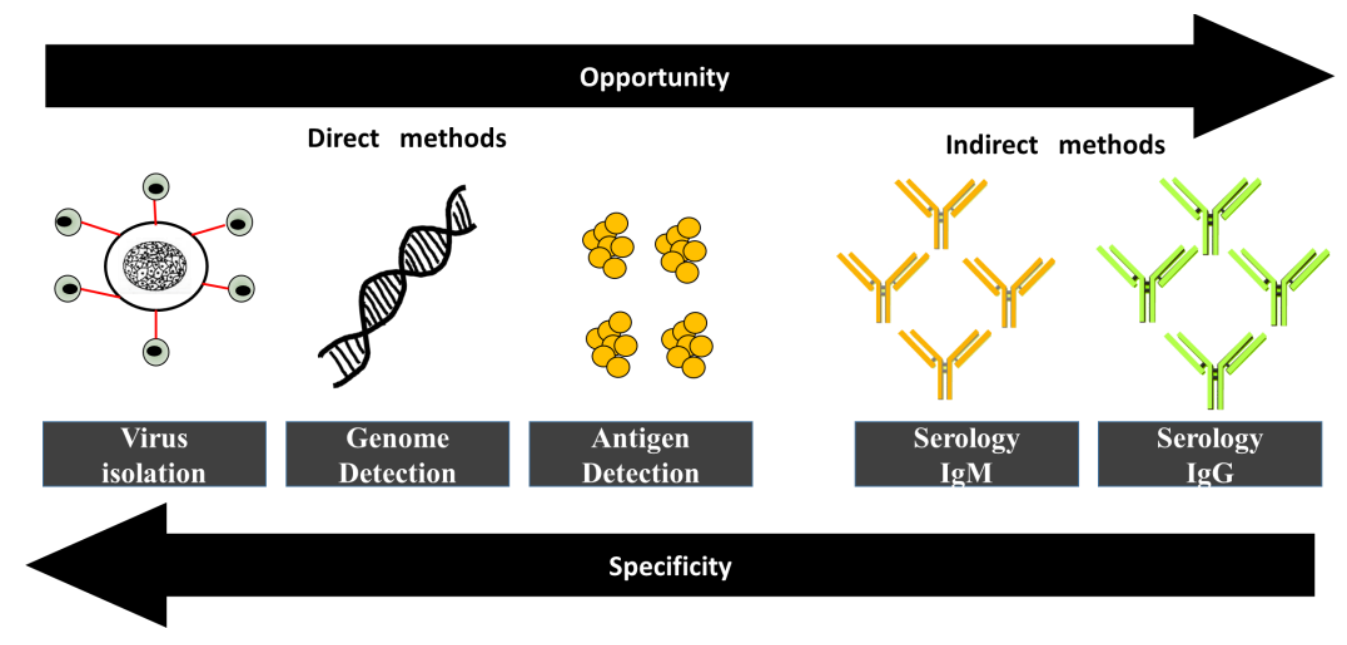

Fig. 3: Comparative laboratory methods of direct and indirect diagnosis of dengue infection. Illustrations were redrawn, according to [17].

\subsubsection{Virus Isolation}

Many studies have recorded the virus isolation methods as the best diagnostic method for detecting dengue infection [20-21]. In this method, the infected blood samples are cultured in a variety of cell lines of either mosquito (AP- 61, Tra-284, AP64, C6/36, and CLA-1 cells) or mammalian (LLCMK2, Vero, and BHK-21 cells) origin or in live mosquitoes. This is followed by the immunofluorescent assays via serotype-specific monoclonal antibodies (mAbs) for virus serotype identification [17]. The virus isolation detection method relies on the cultivation and identification of virus techniques that are sensitive and time-consuming. Although these methods display high specificity in dengue diagnosis, they have greatly tedious steps (long virus isolation time), limited time for culturing virus at the acute phase of infection (2-5 days), and high-cost facilities to protect the cell condition [22].

\subsubsection{Genome Detection}

The dengue genome detection methods are generally discovered by reverse transcriptase polymerase chain reaction (RT-PCR) in serum of dengue patients in the acute phase of the disease. These methods offer several advantages including the ability to differentiate dengue serotypes that have higher specificity when combined with real-time technology such as TaqMan assays [23], and are cheaper than virus isolation methods [22]. However, these methods require specialist operators, expensive reagents and apparatuses, thus restricting their 
use in many developing countries [24-25]. Furthermore, they are also easily contaminated by non-template PCRs present in the laboratory environment [26].

\subsubsection{Antigen Detection}

In recent years, the use of nonstructural protein 1 (NS1) has gained attention as a diagnostic tool of dengue detection [10]. This dengue diagnosis can be done during early stage of dengue infection by detecting the viral antigen in the bloodstream. A newly developed antigen-capture enzyme-linked immunosorbent assay (ELISA) method can be utilized to detect NS1. Dengue patients with primary and secondary (up to 9 days) dengue infections have high concentration of this NS1 antigen. High efficiencies of NS1-ELISA method have led to the commercial development of NS1 capture ELISAs and rapid strip tests. NS1 commercial development has recently been known as the new standard for early dengue diagnostics due to low-technology assays that have high sensitivity and specificity [10]. However, the disadvantage of these methods is that they are unable to differentiate among dengue serotypes. This is due to NS1 being conserved among all four dengue serotypes, and expressed or secreted by infected host cells. Apart from that, it is produced during the dengue virus replication and circulated in serum at high concentration during acute infection [17].

\subsubsection{Serology Tests}

Serological test is the best diagnostic method to detect the presence of immunoglobulins (IgM, IgG and IgA) which are produced in response to dengue virus infection after the acute illness phase (2-7 days). Different levels of response of these antibodies can be measured where the antibody IgG abd IgM rise rapidly after viremia phase as shown in Fig. 1(b). Conventional serological tests include hemagglutination inhibition (HI) [27-28], plaque reduction neutralization test (PRNT) [19], [29] and enzyme-linked immunosorbent assay (ELISA) [30]. Among these tests, IgG/IgM assays using ELISA methods are typically used due to their simplicity of operation, rapid results, and reasonable sensitivity. However, serology tests have reported significant cross-reactivity among flavivirus antibodies, which necessitates multiple serum samples to be derived from the acute and convalescent phases during serological diagnosis, slowing the overall process due to the required incubation period (from a few hours up to two days) thus making the tests less efficient [31]. The automated ELISA system requires a high-level of expertise and expensive equipment. ELISA systems are not always available in hospital, and consume considerable amounts of reagents [28]. Recently, an integrated colorimetric IgG-enzyme-linked immunosorbent assay (IgG-ELISA) has been developed using a lab on compact disc (LOCD) system for dengue detection [32]. Figure 4 shows the detection of $\mathrm{IgG}$ antibody in sera of patients using this sensor.

Although they achieved high sensitivity (95\%) and specificity (100\%) for dengue detection, this work was still at its infancy and needs further improvement in term of its limit of detection and portability. This integrated ELISA method (IgG-ELISA using lab on compact disc) is a cost-effective, rapid, automatic testing method of the purpose of point-of-care testing and has high potential as a dengue diagnostic tool 
(a)

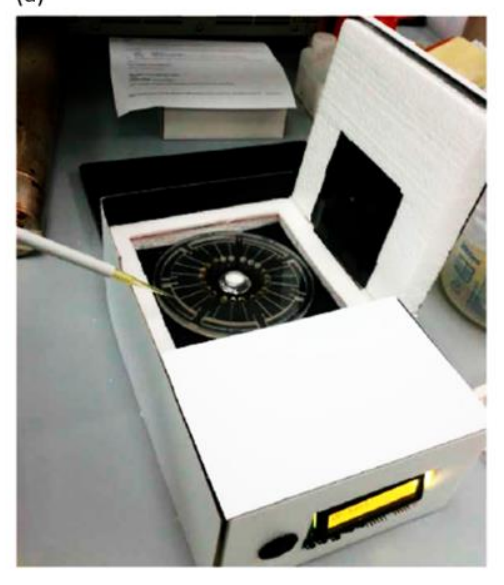

(b)

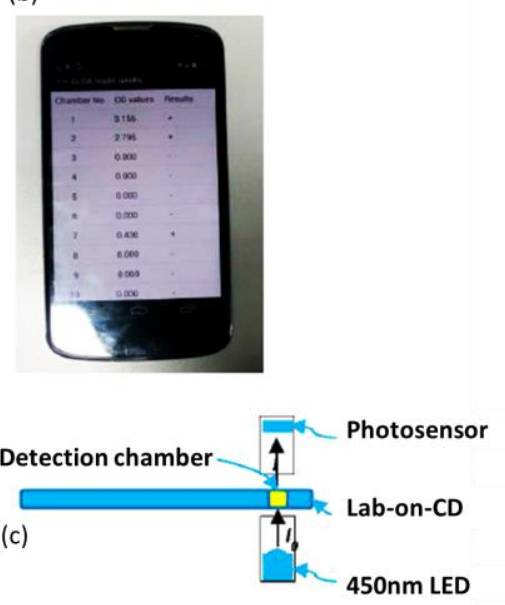

Fig. 4: (a) Prototype of the lab on compact disc (LOCD) ELISA reader; (b) Smartphone application displaying IgG-ELISA test results; (c) Operating principle in evaluating absorbance. Reprinted with permission [32].

\subsection{Recent Trends of Dengue Biosensors}

To overcome the drawbacks of conventional methods, the employment of biosensors has been planned as another technology for speedy detection of dengue and its antibodies. Biosensors are described as analytical devices that involve an integration between a molecular recognition platform with a physicochemical transducer to produce a single detection processing unit [33]. Several biosensor techniques are used in biosensing applications such as electrochemical biosensors (measurement of voltage, current, impedance, and capacitance), piezoelectric biosensors (evaluation on mass sensitivity due to change of frequency) and optical biosensors (light properties are detected through any of the light parameters such as intensity, phase, polarization, or wavelength).

Recently, various types of biosensors have been employed to quantify different targets (analyte probes) for dengue diagnosis. These different targets such as NS1, IgM, IgG, glycoprotein, deoxyribonucleic acid (DNA) and ribonucleic acid (RNA) Flavivirus are capable of detecting the presence and severity of dengue in patient samples. In this work, electrochemical, piezoelectric, and optical biosensors have been described and compared to evaluate their effectiveness in dengue infection.

\subsubsection{Electrochemical Biosensors}

Generally, electrochemical biosensors detect current or impedance changes in the electrode surface owing to redox reaction or surface reactions. These sensors use an electrochemical cell to facilitate chemical reactions through the introduction of electrical energy. The three-electrode system is the electrode configuration most used for in situ electrochemistry system, which consists of working electrode, reference electrode and counter electrode. Figure 5 shows the conventional three-electrode set up and commercial screen printed electrode used in electrochemical measurements. 
Electrochemical impedance spectroscopy (EIS) is one of the electrochemical measurements that is widely used due to its high sensitivity and non-destructive operation. This method measures the changes in the electrode and solution interface due to the interaction with the captured analyte in a real sample. It utilizes a low amplitude sinusoidal perturbation as a function of frequency evaluation of a non-destructive steady-state technique that is capable of probing the relaxation phenomena of like-affinity reactions [34]. Apart from EIS, cyclic voltammetry (CV) and differential pulse voltammetry (DPV) are also commonly used in this detection of dengue, which possess the ability to measure both reduction and oxidation potentials. However, an optimal direct current is required to minimize current interference issues.
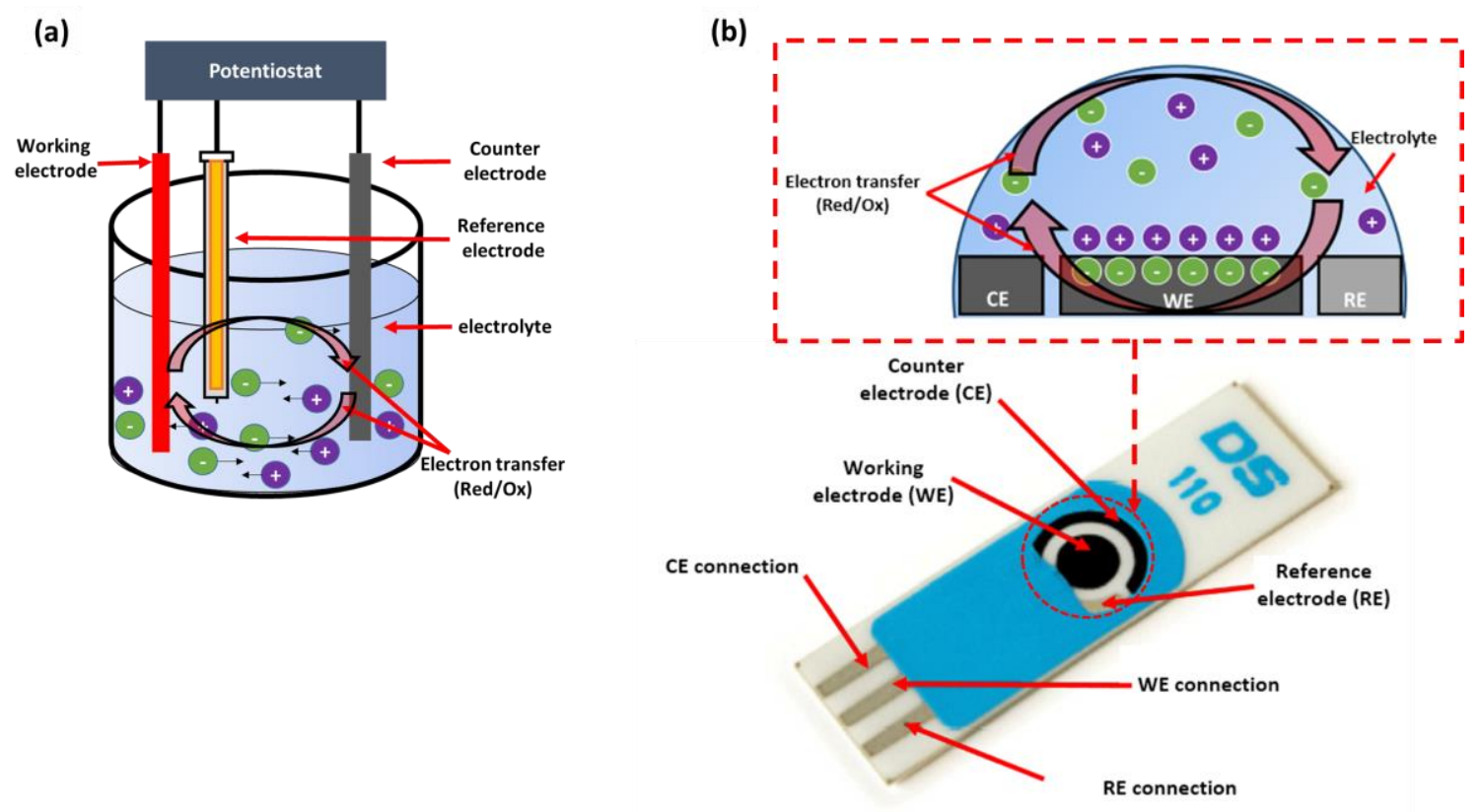

Fig. 5: Three electrode setup for electrochemical measurements using

(a) Conventional and (b) commercial screen printed electrodes.

Illustrations were redrawn, according to [35].

To date, much of work has been done in the development of electrochemical biosensor for dengue detection. Figure 6 shows an impedimetric biosensor to test neat serum for NS1 dengue diagnosis [36]. The commercial screen printed gold electrode (SPGE) biosensors have been utilized via mixed self-assembly monolayer (SAM) application. This activated mixed selfassembly monolayer (SAM) - with N-hydroxysuccinimide-N, N-(3-dimethylaminopropyl)-N'ethylcarbodiimide (NHS-EDC) reagent and bovine serum albumin (BSA) as a blocking agent has been immobilized on the gold electrodes. The impedance response was measured via an aqueous electrolyte of $\mathrm{K}_{3}\left[\mathrm{Fe}(\mathrm{CN})_{6}\right], \mathrm{K}_{4}\left[\mathrm{Fe}(\mathrm{CN})_{6}\right] \cdot 3 \mathrm{H}_{2} \mathrm{O}$. Although their immobilization method was outdated, they obtained a low limit of detection of $3 \mathrm{ngmL}^{-1}$ and $30 \mathrm{ngmL}^{-1}$, in both NS1 protein measurement in phosphate-buffered saline (PBS) and serum samples, respectively. Furthermore, they observed a good selectivity test via $2 \mu \mathrm{gmL}^{-1}$ of fetuin in PBS (blood protein) in order to evaluate possible non-specific interactions with the electrode. Consequently, it showed that fetuin showed a response for less than $3 \%$ of blank samples. This result was in 
contrast to a response of $46 \%$ of blank samples for the specific response to NS1 protein at a clinically relevant level. They also found that new applications into the potential use of this SPGE biosensor for point-of-care (POC) applications for early dengue diagnosis.

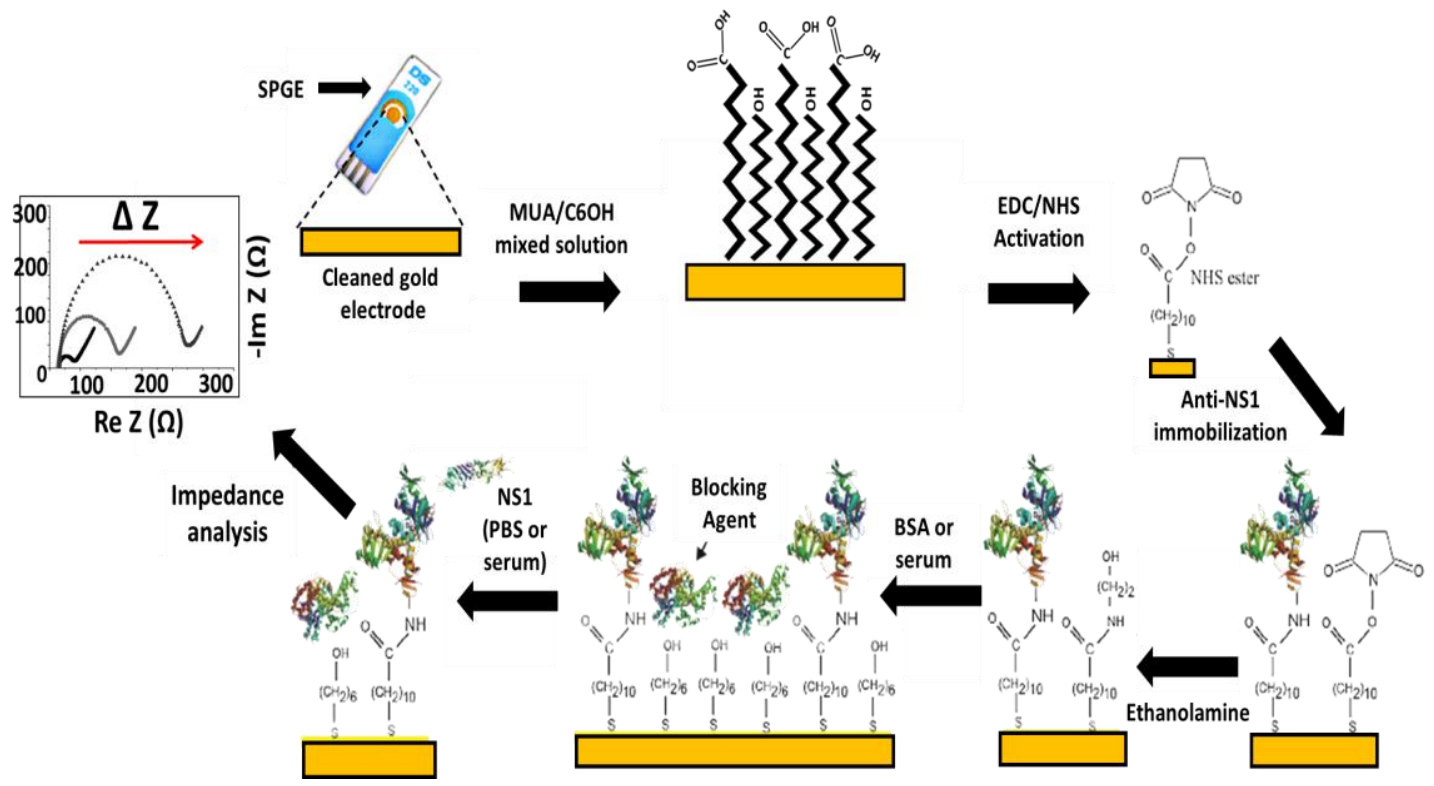

Fig. 6: Step by step process of electrode functionalization with an activated mixed self-assembly monolayer (SAM) for NS1 dengue diagnosis.

Illustrations were redrawn, according to [36].

Figure 7 indicates the working electrode surface has been functionalized via sandwich immunocomplex and immunonanobeads (AuNPs-Ab-Fc) with nanoparticle-linked detection of dengue NS1 antibodies [37]. The use of SPGE sensors enables quantification together with the facility of a lateral flow test strip to detect the analyte dengue NS1 protein in the presence of 5 $\mathrm{mM}$ ferrocene acetic acid. This work had a lower detection limit of $0.5 \mathrm{ngmL}^{-1}$ as compared to Cecchetto's work previously. For selectivity tests, they immobilized non-specific capture antibody (mouse $\mathrm{IgG}$ ) on the surface of SPGE. From these results, no significant changes were observed in the cyclic voltammetry and impedimetric responses of current and impedance responses for NS1 concentration ranging from $0.5 \mathrm{ngmL}^{-1}$ to $400 \mathrm{ngmL}^{-1}$. Although this work was still at its infancy, it offered on-site POC diagnostics for early dengue detection due to its operational simplicity, biocompatibility, disposability, and low cost.

An electrochemical biosensor to evaluate for all four serotypes of dengue virus has been demonstrated [38]. This biosensor was activated via zinc oxide/platinum-palladium ( $\mathrm{ZnO} / \mathrm{Pt}-$ Pd) nanocomposites on a modified fluorine doped tin oxide (FTO) glass plate. It was found that the hybridization between probe DNA(PDNA) and target hybridized DNA (TDNA) was detected by reduction in current via an intercalating agent (methylene blue (MB) with free guanine $\left(3^{\prime} \mathrm{G}\right)$ of ssDNA). They reported high selectivity to dengue detection that was capable of reducing the possibility of false result with the smallest detection and quantification limit, which were $4.3 \times 10^{-5} \mathrm{M}$ and $9.5 \times 10^{-5} \mathrm{M}$, respectively. Owing to that, small low cross-reaction due to no significant change in current response was observed upon addition of non- 
complementary DNA relative to the PDNA. Overall, this genosensor was cost-effective in noble metal catalyst due to the combination of smart nano-materials of $\mathrm{Pd} / \mathrm{ZnO}$ and $\mathrm{Pt} / \mathrm{ZnO}$, thus improving the stability of nano-catalyst in chemical reactions [39].
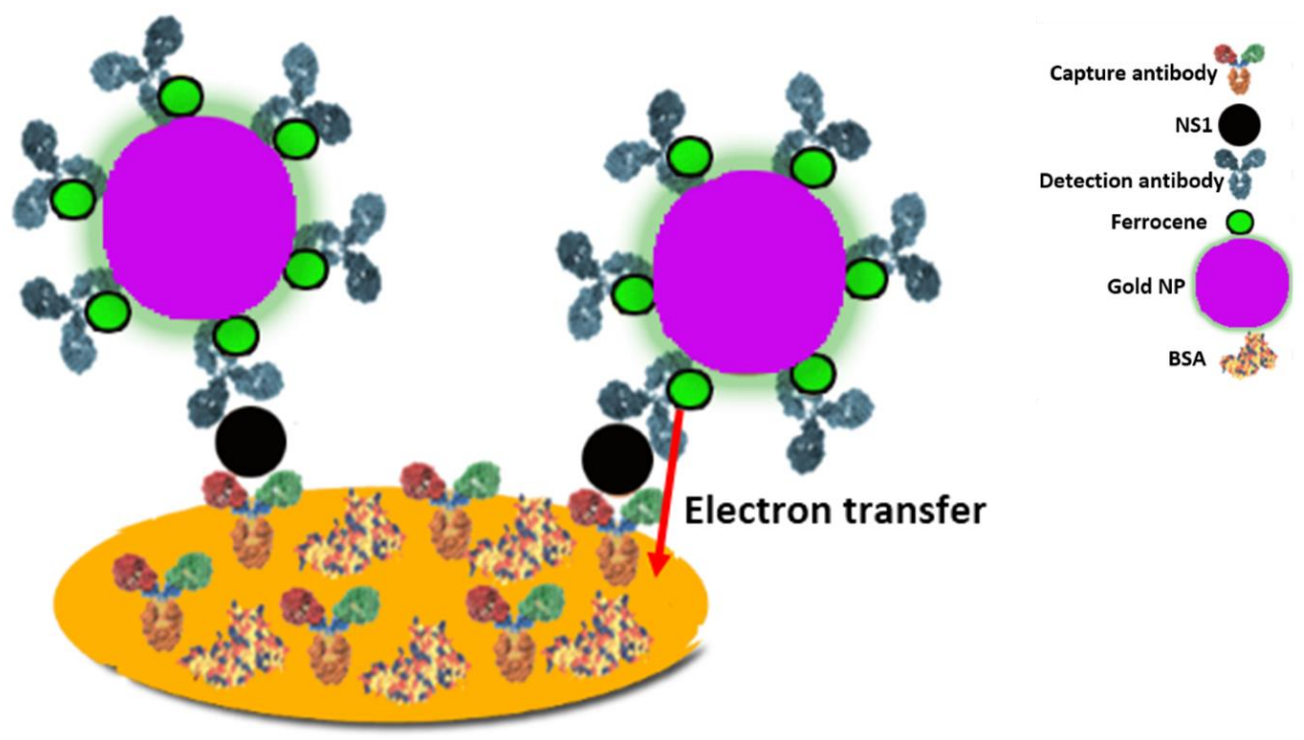

Fig. 7: Formulated immunonanobeads (AuNPs-Ab-Fc) and sandwich immunocomplex formation on SPGE sensor. Illustrations were redrawn, according to [37].

Recently, a molecularly imprinted polymer (MIP)-graphene based electrochemical sensor for dengue and anti-dengue antibodies detection has been reported [40]. The sensor was reported to detect dengue ranging from 1 to $2000 \mathrm{pfu} / \mathrm{mL}$ and between different dengue serotypes and H5N1. It was observed that an MIP functioned as a recognition element, which had the advantage of removing antibody transducers. However, this material lacked the specificity and binding affinity of antibodies.

\subsubsection{Piezoelectric Biosensors}

Most piezoelectric biosensor studies have been conducted using constant resonance devices. Sauerbrey et al. was the first group of researchers who not only developed but also demonstrated the relationship between mass and resonant frequency and recognized the potential usefulness of quartz crystal microbalance (QCM) technology [41]. These QCM sensors are recognized as the best acoustic wave sensors that function effectively for sensing applications as well as in gaseous form and in contact with liquids without excessive damping. Figure 8 shows the conceptual diagram of QCM in liquid bio-sensing. An alternate current (AC) signal is applied to the top and bottom electrodes of AT-quartz to generate acoustic wave energy (resonance frequency). Due to presence of antigens and antibodies deposited at the top electrode; frequency change will be produced due to addition of mass. Apart from QCM sensors, surface acoustic wave (SAW) sensors are also developed as piezoelectric biosensors, especially in non-liquid bio-sensing such as insorption gas, vapor sensors, and sound (noise) detection [42]. In the last decades, the use of piezoelectric biosensors has seen great interest among researchers, specifically in tropical countries for detecting early dengue infection. 


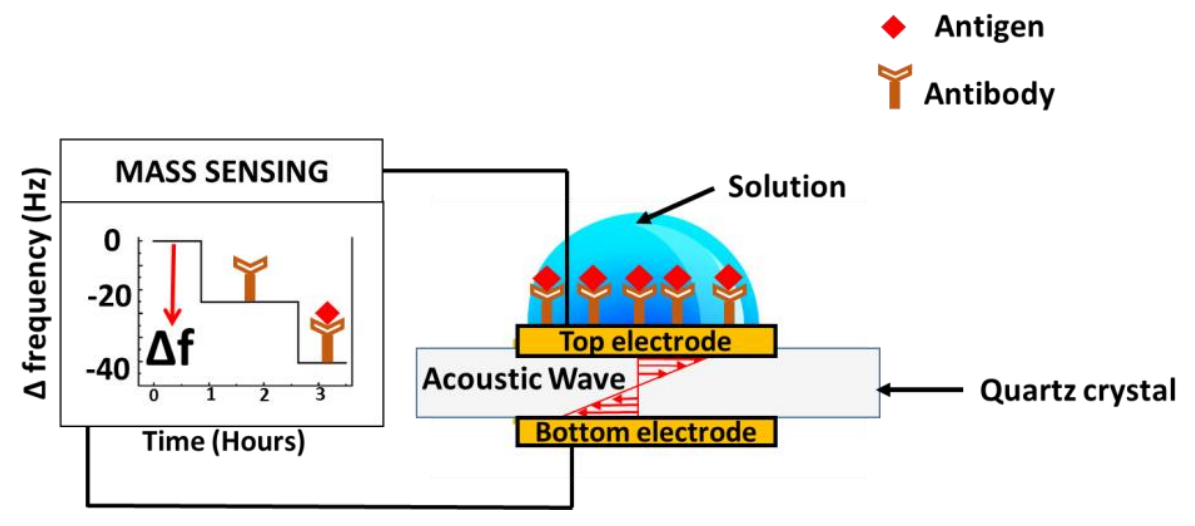

Fig. 8: Application of QCM sensor in liquid bio-sensing.

A highly sensitive DNA-QCM sensor combined with the method of layer-by-layer AuNPprobe amplification for dengue DNA serotype-2 detection has been reported [43]. The change of frequency was recorded for the techniques of probe oligonucleotide immobilization $(\Delta \mathrm{f}=45$ $\mathrm{Hz})$, and DNA hybridization of probes and targets $(\Delta \mathrm{f}=80 \mathrm{~Hz})$. It is followed by the signal amplification of detection in the DNA-QCM system $(\Delta \mathrm{f}=200 \mathrm{~Hz})$ by layer-by-layer AuNP probes using target sequences $(\Delta \mathrm{f}=130 \mathrm{~Hz})$. These techniques were complex due to tedious steps, long incubation time and less selectivity (up to 60\%) for dengue detection. Nevertheless, they observed that the detection limit of $2 \mathrm{PFUmL}^{-1}$ was relatively comparable to the fluorescent (RT-PCR) methods (1-50 PFUmL ${ }^{-1}$ ). Furthermore, this method was less expensive and was label free as compared to RT-PCR methods.

The QCM sensor with a functionalized interface via the monoclonal immunoglobulin $\mathrm{G}$ (IgGNS1) antibodies attachment has been developed [44]. Figure 9 shows the sensor has been modified with bacterial cellulose nanocrystal $(\mathrm{CN})$ thin films for NS1 of dengue detection. This sensor provides a few advantages such as short-time analysis, simplicity, real-time monitoring, and label-free detection. However, it was observed that this sensor was not selective to NS1 dengue detection in serum samples due to high frequency interferences. As a result, it showed that the large variation of detection limit for NS1 detection in PBS and serum samples, which was $0.03 \mu \mathrm{gmL}^{-1}$ and $0.32 \mu \mathrm{gmL}^{-1}$, respectively.

Figure 10 indicates a surface acoustic wave (SAW) dengue sensor in human habitations based on MATLAB simulation and real mosquito flight tones has been demonstrated [45]. The dengue detection was analyzed via the wing beat frequency produced by female Aedes mosquitoes via the feasibility of a SAW sensor (acoustic-based device). Based on the Aedes mosquitoes' gender and genus, which corresponded to a frequency of 400-500 Hz in females and 700-900 Hz in males could be distinguished by this SAW sensor. Decreased resonant peak amplitude with different wing beat frequencies were observed. Consequently, this SAW sensor offered a non-invasive method (no serum samples) for dengue detection, and was the first report of an SAW dengue sensor in acoustic wave sensing. Furthermore, this sensor showed its uniqueness since no surface chemistry modification is performed as compared to other biosensors discussed previously. However, this SAW sensor required an expensive fabrication 
process since it was developed in the cleanroom that required masking followed by metal deposition.

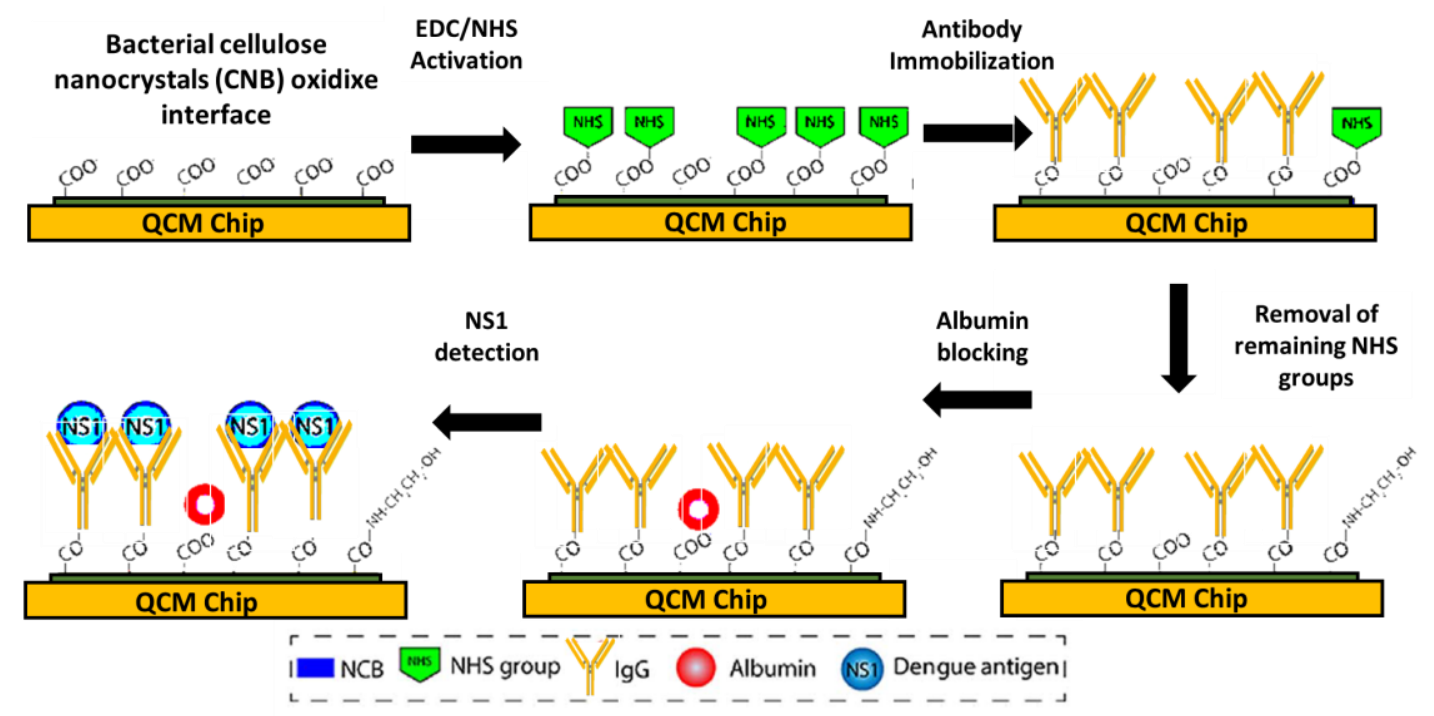

Fig. 9: Schematic representation of sequential immunochip assembly.

Illustrations were redrawn, according to [44].

\subsubsection{Optical Biosensors}

Basically, two types of optical biosensor formats have been recognized, which are optical sensors (commonly known as surface plasmon resonance (SPR sensors)) and optical fibers. SPR comprises an optical system, correlated with the refractive index changes at the surface of the biosensor, caused by a concentration change of the binding medium when the antibodies as the target bind to the immobilized antigens acting as probes. Meanwhile, optical fibers are dependent on the total internal reflection of light and the characterization of a surface by the difference in the angle of incidence of reflected light upon sensor surface modifications. Overall, the use of an electronic system supporting the optoelectronic components is required to allow for data processing for both types of optical biosensors. Currently, a lot of research has been done in the exploitation of dengue optical biosensors [46-48].

Figure 11 depicts a study on 10-minutes of early detection for all four dengue virus serotypes via surface plasmon resonance (SPR) technique [46]. This work has been done to detect the IgM antibody, a chip of gold sensor surface was initially activated with a mixture of EDC/NHS to produce reactive succinimide esters. It was continued by injecting the diluted ligand (each serotype of dengue antigen) with acetate buffer. To deactivate the remaining active esters, the ethanolamine was passed over the sensor surface and the chip was then placed into the SPR device to measure the SPR angle variations for each sample. The success of immobilized antigens was verified via SEM and AFM images of immobilized antigens as shown in Fig. 11 (b,c,d). From the result, it showed that two distinctive types of hills that were observed in 3D AFM images. The first hill exhibited homogeneous, dense, and low gold hills that were established from amine groups. The second hill showed sporadic hills arising from immobilized antigens. 


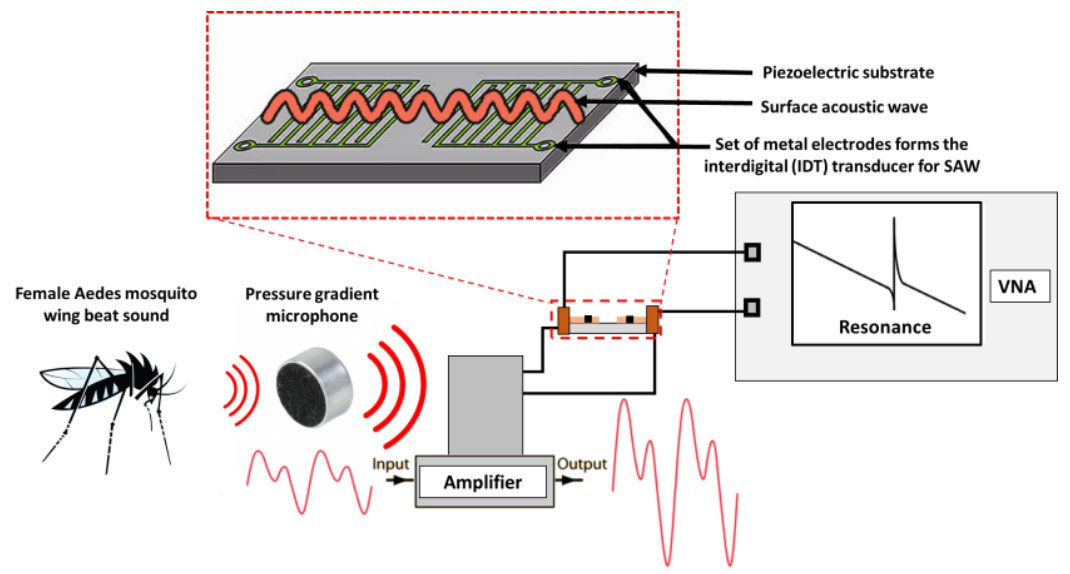

Fig. 10: The vector network analyzer (VNA) was used to measure the resonance frequency SAW sensor to capture the mosquito's wingbeat frequency.

Illustrations were redrawn, according to [45].

(a)

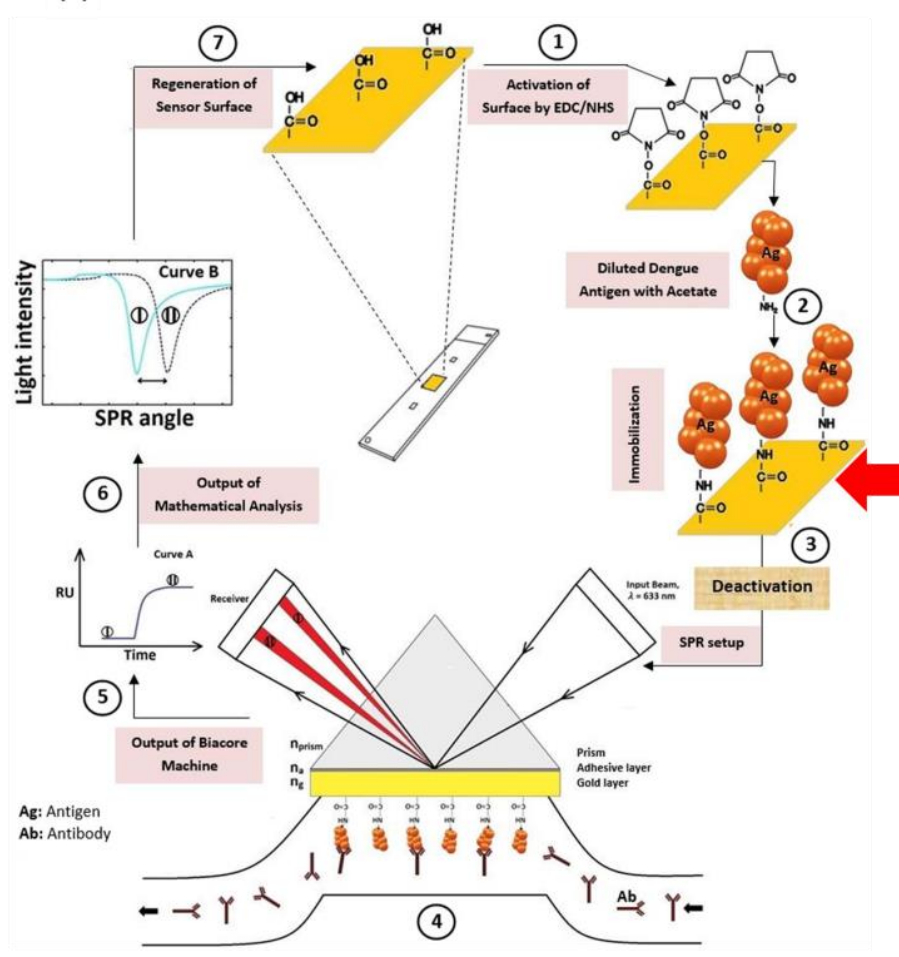

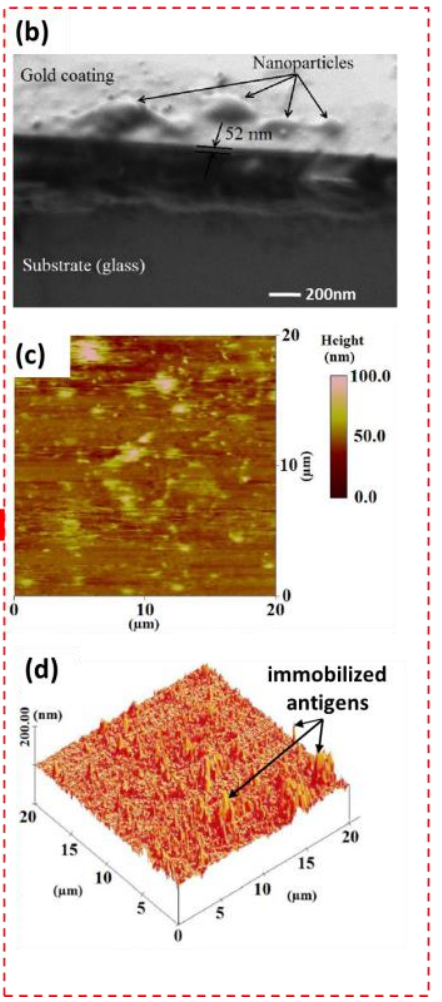

Fig. 11: (a) The SPR dengue virus diagnosis process. (b) The cross-sectional SEM image estimated the gold layer (52 nm thick). The verification of immobilized antigens (c) 2D (d) and 3D AFM images. Reprinted with permission [46].

To date, this group has been continued their projects on kinetic analysis of IgM monoclonal antibodies binding to DENV-2 antigens using the SPR technique [48]. In these projects, prior to dengue sample injection, a chip of gold sensor surface was initially activated with 
immobilization of carboxymethyl-dextran matrix as a linker layer, N-hydroxysuccinimide (NHS) and N-ethyl-N-(dimethylaminopropyl) carbodiimide (EDC). Ethanolamine and $10 \mathrm{mM}$ glycine-HCl solutions are utilized as a blocking agent on the gold surface. Finally, it was followed by the IgM monoclonal antibodies addition to the analyte flow. They observed that the binding of analyte to the immobilized antigens caused a rise in the refractive index of the chip surface as compared to their previous study as described previously. Thus, although SPR techniques used for both studies (2014 and 2017) recorded good sensitivity (83-93\%) and specificity $(100 \%)$ for all four dengue virus serotypes and detection limit of $2 \times 10^{5} \mathrm{PFUmL}^{-1}$ for DENV-2 antigen, the use of a commercial BIAcore system for SPR measurements used in both studies was very expensive [49].

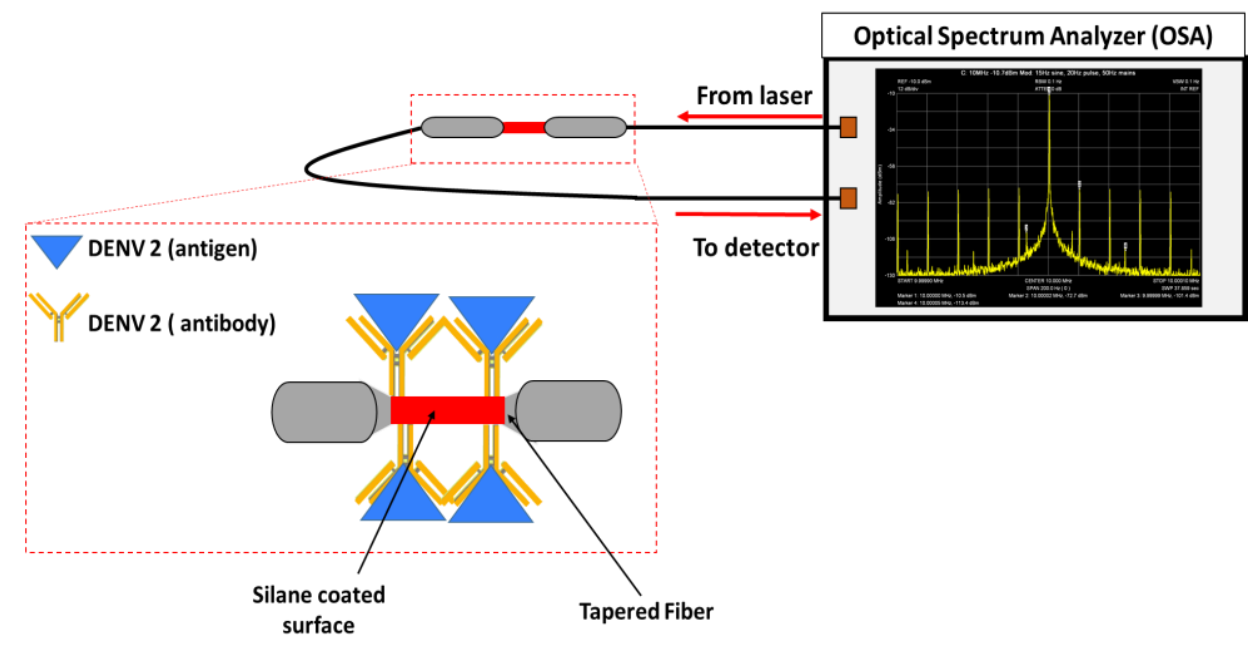

Fig. 12: The OSA was used to laser-excite into

one end of the tapered fiber sensor, and monitor the transmission spectrum

from the other end. The DENV-2 (E protein) specific binding of antigens-antibodies in the tapered region could be analyzed through phase shift of the spectrum. Illustrations were redrawn, according to [47].

A study on 15-minutes of label-free detection of DENV 2 via tapered fiber sensor has been proposed [47]. This sensor was fabricated via a standard single-mode fiber with cladding and core diameters of $125 \mu \mathrm{m}$ and $8 \mu \mathrm{m}$. To realize the successful coating of the tapered optical fiber with antibodies of DENV 2, a treatment of tapered region via sodium hydroxide was initially done to offer a functionalization of hydroxyl group $(-\mathrm{OH})$ onto the surface. The significance of this treatment was to promote a high selectivity attachment of a silant agent (3aminopropyl) tri-ethoxysilane, APTES is used to activate the non-organic fiber surface layer to bind with the organic compound such as protein. Then, the use of glutaraldehyde was done to enhance the homogeneity of the antibody immobilization on the surface of the tapered fiber prior to binding antibodies specific to E proteins of DENV-2. Finally, variation of concentration of antigens specific to recombinant monoclonal antibodies to DENV-2 E proteins was established to observe an immune complex on the tapered region. All these steps were observed via optical spectrum analyzer (OSA) to record any changes on the spectrum signal due to molecules bound on the taper surface as shown in Fig. 12. Consequently, this sensor showed that sensitivity and detection limit values of $5.02 \mathrm{~nm} / \mathrm{nM}$ and $1 \mathrm{pM}$ for detection of DENV-2. For the selectivity test, the use of avidin as a negative control observed a no shift spectrum 
output, thus no additional layer was formed. Table 1 and Table 2 list recent biosensor methods and development for detection of dengue as described in this work.

Table 1: Comparison of recent biosensors methods for detection of dengue

\begin{tabular}{|c|c|c|}
\hline Method & Advantages & Disadvantages \\
\hline $\begin{array}{c}\text { Electrochemical } \\
\text { sensors } \\
{[36-38]}\end{array}$ & $\begin{array}{ll}\text { 1. } & \text { Cost effective } \\
\text { 2. } & \text { Ease of operation } \\
\text { 3. } & \text { Small analyte volumes } \\
\text { 4. } & \text { Label-free detection }\end{array}$ & $\begin{array}{l}\text { 1. Less sensitive in non-specific binding } \\
\text { 2. Slow measurement } \\
\text { 3. SPGE cannot be reused }\end{array}$ \\
\hline $\begin{array}{c}\text { Piezoelectric: } \\
\text { Quartz crystal } \\
\text { microbalance (QCM) } \\
{[43-44]}\end{array}$ & 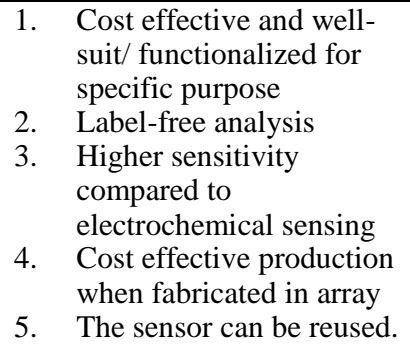 & $\begin{array}{l}\text { 1. Very fragile } \\
\text { 2. Limit the sensor sensitivity when } \\
\text { react in liquid sensing resonances } \\
\text { frequency } \\
\text { 3. The sensitivity of sensor is dependent } \\
\text { on thickness of quartz }\end{array}$ \\
\hline $\begin{array}{l}\text { Piezoelectric: } \\
\text { Surface acoustic } \\
\text { wave (SAW) } \\
{[45]}\end{array}$ & 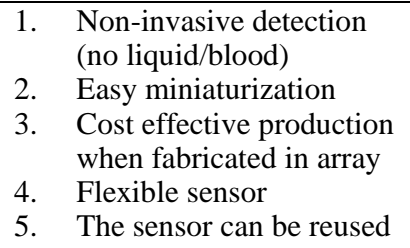 & $\begin{array}{l}\text { 1. Expensive of sensor fabrication } \\
\text { process } \\
\text { 2. Not suitable for liquid sensing }\end{array}$ \\
\hline $\begin{array}{c}\text { Optical: } \\
\text { Surface Plasmon } \\
\text { Resonance (SPR) } \\
{[46],[48]}\end{array}$ & $\begin{array}{l}\text { 1. Higher sensitive detection } \\
\text { as compared to } \\
\text { electrochemical and } \\
\text { piezoelectric sensing } \\
\text { 2. Ease of handling }\end{array}$ & 1. Extremely expensive instrument \\
\hline
\end{tabular}


Table 2: Recent development of dengue biosensors activities

\begin{tabular}{|c|c|c|c|c|c|}
\hline Samples & Approach & Methods & LOD & Response Time & Ref. \\
\hline $\begin{array}{l}\text { DENV, } \\
\text { NS1-antigen }\end{array}$ & SPGE activated with a mixed-SAM layer & CV,EIS & $\begin{array}{l}\text { PBS }=3 \mathrm{ngmL}^{-1} \\
\text { Serum }=30 \text { ngmL }\end{array}$ & $30 \mathrm{~min}$ & {$[36]$} \\
\hline $\begin{array}{l}\text { DENV, } \\
\text { NS1-antigen }\end{array}$ & $\begin{array}{l}\text { SPGE Lateral Flow modified with sandwich } \\
\text { immunocomplex and immunonanobeads }\end{array}$ & CV,EIS & $\mathrm{PBS}=0.5 \mathrm{ngmL}^{-1}$ & $30 \mathrm{~min}$ & {$[37]$} \\
\hline $\begin{array}{l}\text { DENV-1,2,3,4 } \\
\quad \text { (DNA) }\end{array}$ & $\begin{array}{l}\text { (FTO) glass plate modified with nano material } \\
\qquad(\mathrm{ZnO} / \mathrm{Pt}-\mathrm{Pd})\end{array}$ & CV,DPV & $4.3 \times 10^{-5} \mathrm{M}$ & $120 \mathrm{~min}$ & {$[38]$} \\
\hline $\begin{array}{l}\text { DENV-2 } \\
\text { (DNA) }\end{array}$ & $\begin{array}{l}\text { QCM modified with Layer-by-layer AuNP-probe } \\
\text { amplification }\end{array}$ & QCM & $2 \mathrm{PFUmL}^{-1}$ & Not mentioned & {$[43]$} \\
\hline $\begin{array}{l}\text { DENV, } \\
\text { NS1 }\end{array}$ & $\begin{array}{l}\text { QCM modified with bacterial cellulose } \\
\text { nanocrystals }(\mathrm{CN}) \text { thin films }\end{array}$ & QCM & $\begin{aligned} \text { PBS } & =0.03 \mu \mathrm{gmL}^{-1} \\
\text { Serum } & =0.32 \mu \mathrm{gmL}^{-1}\end{aligned}$ & Not mentioned & {$[44]$} \\
\hline $\begin{array}{l}\text { Dengue } \\
\text { Mosquitos }\end{array}$ & $\begin{array}{c}\text { SAW sensor in human habitations based on real } \\
\text { mosquito flight tones }\end{array}$ & SAW & Not mentioned & Not mentioned & [45] \\
\hline $\begin{array}{l}\text { DENV-1,2,3,4 } \\
\text { (NS1-Antigen) }\end{array}$ & Gold chip modified Amine coupling (NHS/EDC) & SPR & $\begin{array}{c}\text { Sensitivity }=83-93 \% \\
\text { specificity }=100 \%\end{array}$ & $10 \mathrm{~min}$ & {$[46]$} \\
\hline DENV-2 antigen & $\begin{array}{l}\text { Gold chip modified with Amine coupling } \\
\text { (NHS/EDC) in PBS/Gly using SAM layer }\end{array}$ & SPR & $2 \times 10^{5} \mathrm{PFUmL}^{-}$ & $10 \mathrm{~min}$ & [48] \\
\hline DENV-2 antigen & Tapered fiber modified with APTES & $\begin{array}{l}\text { Optical } \\
\text { Fiber }\end{array}$ & $1 \mathrm{pM}$ & $15 \min$ & {$[47]$} \\
\hline
\end{tabular}




\section{CONCLUSION}

This work compares the current laboratory diagnosis methods for detection of dengue virus infection. It was observed that virus isolation, RT-PCR, and serology methods are the most direct approach to dengue diagnosis. However, these methods require tedious steps, expensive requirements, and expert staff. In this work, various type of biosensors such as electrochemical biosensors (measurement of voltage, current, impedance, and capacitance), piezoelectric biosensors (evaluation on mass sensitivity due to change of frequency), and optical biosensors (light properties are detected through any of the light parameters such as intensity, phase, polarization or wavelength) have been described and compared to evaluate their effectiveness in dengue detection. Among these biosensors, optical sensing offers the best method due to its high sensitivity as compared to others, although it is popularly known as an expensive method. Alternatively, the use of electrochemical and piezoelectric biosensors (QCM) is highly recommended for detection of dengue due to ease-to-use, low cost (since it requires less reagent), disposability, and minimal sample preparation. These approaches have the potential to improve chances of survival, particularly in resourcelimited countries.

\section{ACKNOWLEDGEMENT}

This research is a collaborative research between Linkoping University (Sweden), XLIM Research Institute of Limoges University (France) and International Islamic University Malaysia. It is funded by the Swedish Research Council (2014-4254) and the Malaysian Ministry of Higher Education under FRGS15-217-0458.

\section{REFERENCES}

[1] Special Programme for Research and Training in Tropical Diseases, World Health Organization (Eds.), (2009). Dengue: guidelines for diagnosis, treatment, prevention, and control, New ed. ed. TDR : World Health Organization, Geneva.World Health Organization and the Special Programme for Research and Training in Tropical Diseases (TDR)

[2] Gubler, D. J. (2002). Epidemic dengue/dengue hemorrhagic fever as a public health, social and economic problem in the 21st century. Trends in Microbiology, 10(2): 100-103.

[3] Wilder-Smith, A., Vannice, K. S., Hombach, J., Farrar, J., \& Nolan, T. (2016). Population perspectives and World Health Organization recommendations for CYD-TDV dengue vaccine. The Journal of Infectious Diseases, 214(12): 1796-1799.

[4] Wang, W.K. and Gubler, D.J., (2018). Potential point-of-care testing for dengue virus in the field. Journal of clinical microbiology, 56(5), e00203-18.

[5] Low, G.K.K., Ogston, S.A., Yong, M.H., Gan, S.C. and Chee, H.Y., (2018). Global dengue death before and after the new World Health Organization 2009 case classification: A systematic review and meta-regression analysis. Acta tropica, 182: 237-245

[6] Liu, L., Dehning, M., Phipps, A., Swienton, R., Harris, C., \& Klein, K. (2017). Clinical Update on Dengue, Chikungunya, and Zika: What We Know at the Time of Article Submission. Disaster Medicine and Public Health Preparedness, 11(3): 290-299.

[7] Vaughn, D. W., Green, S., Kalayanarooj, S., Innis, B. L., Nimmannitya, S., Suntayakorn, S.,\& Nisalak, A. (1997). Dengue in the early febrile phase: viremia and antibody responses. Journal of Infectious Diseases, 176(2): 322-330.

[8] Green, S., Vaughn, D. W., Kalayanarooj, S., Nimmannitya, S., Suntayakorn, S., Nisalak, A., \& Ennis, F. A. (1999). Early immune activation in acute dengue illness is related to development of plasma leakage and disease severity. The Journal of infectious diseases, 179(4): 755-762. 
[9] Zhang, B., Salieb-Beugelaar, G. B., Nigo, M. M., Weidmann, M., \& Hunziker, P. (2015). Diagnosing dengue virus infection: rapid tests and the role of micro/nanotechnologies. Nanomedicine: Nanotechnology, Biology and Medicine, 11(7): 1745-1761.

[10] Muller, D. A., Depelsenaire, A. C., \& Young, P. R. (2017) Clinical and laboratory diagnosis of dengue virus infection. The Journal of Infectious Diseases, 215.Suppl_2: S89-S95.

[11] Oliveira, M. D., Nogueira, M. L., Correia, M. T., Coelho, L. C., \& Andrade, C. A. (2011). Detection of dengue virus serotypes on the surface of gold electrode based on Cratylia mollis lectin affinity. Sensors and Actuators B: Chemical, 155(2): 789-795.

[12] Rashid, J. I. A., Yusof, N. A., Abdullah, J., Hashim, U., \& Hajian, R. (2016). Surface modifications to boost sensitivities of electrochemical biosensors using gold nanoparticles/silicon nanowires and response surface methodology approach. Journal of Materials Science, 51(2): 1083-1097.

[13] den, B. G., \& Hulanicki, A. (1983). Recommendations for the usage of selective, selectivity and related terms in analytical chemistry. Pure and Applied Chemistry, 55(3): 553-556.

[14] Persson, B.-A., \& Vessman, J. (2001). The use of selectivity in analytical chemistry-Some considerations. TrAC Trends in Analytical Chemistry, 20(10): 526-532.

[15] Laidler, K. J. (1996). A glossary of terms used in chemical kinetics, including reaction dynamics (IUPAC Recommendations 1996). Pure and Applied Chemistry, 68(1): 149-192.

[16] Long, G. L., \& Winefordner, J. D. (1983). Limit of detection. A closer look at the IUPAC definition. Analytical Chemistry, 55(7): 712A-724A.

[17] Peeling, R. W., Artsob, H., Pelegrino, J. L., Buchy, P., Cardosa, M. J., Devi, S., ... Yoksan, S. (2010, December 1). Evaluation of diagnostic tests: dengue [Comments and Opinion].

[18] Chua, K. B., Mustafa, B., Wahab, A. A. H., Chem, Y. K., Khairul, A. H., Kumarasamy, V., Rasid, A. K. (2011). A comparative evaluation of dengue diagnostic tests based on singleacute serum samples for laboratory confirmation of acute dengue. The Malaysian Journal of Pathology, 33(1): 13-20.

[19] Raengsakulrach, B., Nisalak, A., Maneekarn, N., Yenchitsomanus, P., Limsomwong, C., Jairungsri, A.,others. (2002). Comparison of four reverse transcription-polymerase chain reaction procedures for the detection of dengue virus in clinical specimens. Journal of Virological Methods, 105(2): 219-232.

[20] Darwish, N. T., Alias, Y. B., \& Khor, S. M. (2015). An introduction to dengue-disease diagnostics. TrAC Trends in Analytical Chemistry, 67: 45-55.

[21] Darwish, N. T., Sekaran, S. D., \& Khor, S. M. (2017). Point-of-Care Tests: A Review of Advances in the Emerging Diagnostic Tools for Dengue Virus Infection. Sensors and Actuators B: Chemical, 255(3): 3316-3331.

[22] Parkash, O., \& Shueb, R. H. (2015). Diagnosis of Dengue Infection Using Conventional and Biosensor Based Techniques. Viruses, 7(10): 5410-5427.

[23] Kong, Y. Y., Thay, C. H., Tin, T. C., \& Devi, S. (2006). Rapid detection, serotyping and quantitation of dengue viruses by TaqMan real-time one-step RT-PCR. Journal of Virological Methods, 138(1-2):123-130.

[24] Cavalcanti, I. T., Silva, B. V. M., Peres, N. G., Moura, P., Sotomayor, M. D. P. T., Guedes, M. I. F., \& Dutra, R. F. (2012). A disposable chitosan-modified carbon fiber electrode for dengue virus envelope protein detection. Talanta, 91: 41-46.

[25] Fry, S. R., Meyer, M., Semple, M. G., Simmons, C. P., Sekaran, S. D., Huang, J. X., ... Young, P. R. (2011). The diagnostic sensitivity of dengue rapid test assays is significantly enhanced by using a combined antigen and antibody testing approach. PLoS Neglected Tropical Diseases, 5(6): e1199.

[26] Watthanaworawit, W., Turner, P., Turner, C. L., Tanganuchitcharnchai, A., Jarman, R. G., Blacksell, S. D., \& Nosten, F. H. (2011). A prospective evaluation of diagnostic methodologies for the acute diagnosis of dengue virus infection on the Thailand-Myanmar border. Transactions of the Royal Society of Tropical Medicine and Hygiene, 105(1): 3237.

[27] Wright, W. F., \& Pritt, B. S. (2012). Update: The diagnosis and management of dengue virus infection in North America. Diagnostic Microbiology and Infectious Disease, 73(3):215220. 
[28] Chutinimitkul, S., Payungporn, S., Theamboonlers, A., \& Poovorawan, Y. (2005). Dengue typing assay based on real-time PCR using SYBR Green I. Journal of Virological Methods, 129(1): 8-15.

[29] Sirivichayakul, C., Sabchareon, A., Limkittikul, K., \& Yoksan, S. (2014). Plaque reduction neutralization antibody test does not accurately predict protection against dengue infection in Ratchaburi cohort, Thailand. Virology Journal, 11(1): 48.

[30] Balmaseda, A., Guzmán, M. G., Hammond, S., Robleto, G., Flores, C., Téllez, Y., ... Sandoval, E. (2003). Diagnosis of dengue virus infection by detection of specific immunoglobulin $\mathrm{M}(\operatorname{IgM})$ and $\operatorname{Ig} \mathrm{A}$ antibodies in serum and saliva. Clinical and Diagnostic Laboratory Immunology, 10(2): 317-322.

[31] F. R. R., Prazeres, D. M. F., \& Lima-Filho, J. L. (2005). Trends in dengue diagnosis. Reviews in Medical Virology, 15(5): 287-302.

[32] Thiha, A., \& Ibrahim, F. (2015). A colorimetric enzyme-linked immunosorbent assay (ELISA) detection platform for a point-of-care dengue detection system on a lab-oncompact-disc. Sensors, 15(5): 11431-11441.

[33] Miserere, S., \& Merkoçi, A. (2015). Microfluidic Electrochemical Biosensors: Fabrication and Applications. In Lab-on-a-Chip Devices and Micro-Total Analysis Systems, Springer. pp 141-160.

[34] Zainuddin, A. A., Nordin, A. N., Rahim, R. A., Ralib, A. A. M., Khan, S., Guines, C., ... Pothier, A. (2018). Verification of Quartz Crystal Microbalance Array using Vector Network Analyzer and OpenQCM. Indonesian Journal of Electrical Engineering and Computer Science, 10(1): 84-93.

[35] Katz, E., \& Willner, I. (2003). Probing biomolecular interactions at conductive and semiconductive surfaces by impedance spectroscopy: routes to impedimetric immunosensors, DNA-sensors, and enzyme biosensors. Electroanalysis, 15(11): 913-947.

[36] Cecchetto, J., Carvalho, F. C., Santos, A., Fernandes, F. C., \& Bueno, P. R. (2015). An impedimetric biosensor to test neat serum for dengue diagnosis. Sensors and Actuators B: Chemical, 213:150-154.

[37] Sinawang, P. D., Rai, V., Ionescu, R. E., \& Marks, R. S. (2016). Electrochemical lateral flow immunosensor for detection and quantification of dengue NS1 protein. Biosensors and Bioelectronics, 77:400-408.

[38] Singhal, C., Pundir, C. S., \& Narang, J. (2017). A genosensor for detection of consensus DNA sequence of Dengue virus using $\mathrm{ZnO} / \mathrm{Pt}-\mathrm{Pd}$ nanocomposites. Biosensors and Bioelectronics, 97:75-82.

[39] Bao, Z., Yuan, Y., Leng, C., Li, L., Zhao, K., \& Sun, Z. (2017). One-pot synthesis of noble metal/zinc oxide composites with controllable morphology and high catalytic performance. ACS Applied Materials \& Interfaces, 9(19): 16417-16425.

[40] Navakul, K., Warakulwit, C., Yenchitsomanus, P., Panya, A., Lieberzeit, P. A., \& Sangma, C. (2017). A novel method for dengue virus detection and antibody screening using a graphene-polymer based electrochemical biosensor. Nanomedicine: Nanotechnology, Biology and Medicine, 13(2): 549-557.

[41] Sauerbrey, G. (1959). The use of quartz oscillators for weighing thin layers and for microweighing. Z. Fur. Phys., 155, 206-222. Retrieved from

[42] A. Arnau (2004), Piezoelectric transducers and applications, Springer. Switzerland.

[43] Chen, S.-H., Chuang, Y.-C., Lu, Y.-C., Lin, H.-C., Yang, Y.-L., \& Lin, C.-S. (2009). A method of layer-by-layer gold nanoparticle hybridization in a quartz crystal microbalance DNA sensing system used to detect dengue virus. Nanotechnology,

[44] Pirich, C. L., de Freitas, R. A., Torresi, R. M., Picheth, G. F., \& Sierakowski, M. R. (2017). Piezoelectric immunochip coated with thin films of bacterial cellulose nanocrystals for dengue detection. Biosensors and Bioelectronics, 92: 47-53.

[45] Salim, Z. T., Hashim, U., Arshad, M. K. M., Fakhri, M. A., \& Salim, E. T. (2017). Frequency-based detection of female Aedes mosquito using surface acoustic wave technology: Early prevention of dengue fever. Microelectronic Engineering, 179: 83-90. 
[46] Jahanshahi, P., Zalnezhad, E., Sekaran, S. D., \& Adikan, F. R. M. (2014). Rapid immunoglobulin M-based dengue diagnostic test using surface plasmon resonance biosensor. Scientific Reports, 4: 3851.

[47] Kamil, Y. M., Bakar, M. A., Mustapa, M. A., Yaacob, M. H., Abidin, N. H. Z., Syahir, A., Mahdi, M. A. (2018). Label-free Dengue E protein detection using a functionalized tapered optical fiber sensor. Sensors and Actuators B: Chemical, 257: 820-828.

[48] Jahanshahi, P., Wei, Q., Jie, Z., Ghomeishi, M., Sekaran, S. D., \& Mahamd Adikan, F. R. (2017). Kinetic analysis of IgM monoclonal antibodies for determination of dengue sample concentration using SPR technique. Bioengineered, 8(3): 239-247.

[49] Rich, R. L., \& Myszka, D. G. (2004). Why you should be using more SPR biosensor technology. Drug Discovery Today: Technologies, 1(3): 301-308. 